\title{
Penanggulangan fatalitas korban kecelakaan lalu lintas di kawasan Tugurejo Ngasem Kediri, Jawa Timur
}

\author{
Preventing fatality of traffic accident victims in Tugurejo, in the Ngasem \\ District of Kediri Regency, East Java
}

\author{
Fatikh Dedy Setiawan ${ }^{\bowtie}$ \\ Polda Jawa Timur \\ Surabaya, 60231, Jawa Timur, Indonesia \\ E-mail of corresponding author: fatikh.dedy.setiawan@gmail.com
}

\begin{abstract}
Abstrak
Kebutuhan transportasi lalu lintas saat ini semakin meningkat. Ini sebanding dengan pertumbuhan jumlah penduduk yang ada. Dengan semakin meningkatnya jumlah penduduk tersebut, maka meningkat pula potensi kecelakaan yang dapat terjadi. Penelitian ini bertujuan untuk menanggulangi fatalitas korban kecelakaan lalu lintas di kawasan Desa Tugurejo, Kecamatan Ngasem, Kabupaten Kediri. Dalam penelitian ini pendekatan yang digunakan adalah kualitatif dengan menggunakan metode studi kasus. Hasil penelitian menunjukkan bahwa upaya kepolisian daerah Kediri dalam mengatasi kematian korban kecelakaan lalu lintas dilakukan dengan tiga pendekatan berbeda yaitu pre-emptif, preventif dan represif. Dalam pendekatan pre-emtif, pendidikan publik ditekankan mengenai pelatihan darurat pertolongan pertama (PPGD), kegiatan kepolisian Goes To School, difokuskan pada pemberdayaan masyarakat dan kampanye keselamatan lalu lintas melalui spanduk, baliho, dan media lainnya. Dalam pendekatan preventif, dilakukan melalui turjawali, serta melakukan kerjasama lintas sektoral dengan keterlibatan badan lain di luar kepolisian nasional melalui program SI PEKA. Selanjutnya, pendekatan represif adalah untuk melakukan operasi rutin dan operasi bersama dalam rangka meminimalkan jumlah kematian korban kecelakaan lalu lintas.
\end{abstract}

Kata kunci: lalu lintas; kecelakaan; fatalitas; kepolisian; pencegahan

\begin{abstract}
As population grows, the need for transportation increases correspondingly. The growing number of people on the road will inevitably increase the probability of accidents to occur. This study aims to address the fatalities in traffic accidents in Tugurejo, in the Ngasem District of Kediri Regency. In this qualitative case study, the results show that the Kediri Police Department's efforts to reduce the number of fatalities in traffic accidents are carried out in three different approaches: preemptive, preventive, and repressive. The preemptive approach includes educating the public through First Aid Training, Police Goes to School, community empowering, and traffic safety campaign using banners, billboards, and other media. The preventive approach includes implementing TURJAWALI (arranging, guarding, escorting, and patrolling) and conducting cross-sectoral cooperation with external agencies through SI PEKA program. Lastly, the repressive approach includes conducting routine operations and joint operations in order to minimize the number of fatalities in traffic accidents.
\end{abstract}

Keywords: traffic; accident; fatality; police; prevention

\section{Pendahuluan}

Kebutuhan transportasi lalu lintas saat ini semakin meningkat (McGee 1994; Dick 2000). Ini sebanding dengan pertumbuhan jumlah penduduk yang ada. Tingginya angka pertumbuhan jumlah penduduk faktanya berbanding lurus dengan penjualan kendaraan bermotor di Indonesia (Prayitno 2007; Ridho \& Raharjo 2018). Hal ini berdampak dengan timbulnya permasalahan pada sarana dan prasarana lalu lintas (Firmansyah 2009; Wicaksono et al. 2014; Gunoto et al. 2016). Kepadatan volume lalu lintas menyebabkan akses jalan sulit untuk dilalui, dan berbagai aktivitas pengguna jalan menjadi tidak nyaman, sehingga secara tidak langsung menimbulkan risiko permasalahan lalu lintas, seperti kemacetan dan kecelakaan yang berdampak pada turunnya kinerja pelayanan dibidang lalu lintas dan angkutan jalan (Azizirrahman et al. 2015; Parwita 2019; Putra 2019). 
Menurut Global Status Report on Road Safety (2013), sebanyak 1,24 juta korban meninggal tiap tahun di seluruh dunia dan 20-50 juta orang mengalami luka akibat kecelakaan lalu lintas. WHO (2015) menyebutkan bahwa kecelakaan lalu lintas menjadi penyebab utama kematian anak di dunia dengan rata-rata angka kematian 1000 anak dan remaja setiap harinya pada rentang usia 10-24 tahun. Kecelakaan lalu lintas di Indonesia dalam tiga tahun terakhir ini menjadi pembunuh terbesar ketiga setelah penyakit jantung koroner dan tuberculosis berdasarkan penilaian oleh WHO (Hidayati 2016; Santosa \& Mahyuddin 2017; Soehodho 2017).

Dalam konferensi pers Indonesia Road Safety Award (IRSA) 2016 di Jakarta, Kepala Bagian Keamanan dan Keselamatan Korlantas Polri Kombes Indra Gautama, menjelaskan bahwa jumlah korban meninggal akibat kecelakaan lalu lintas saat ini jauh lebih tinggi dibandingkan korban meninggal akibat narkoba. Angka fatalitas korban meninggal dunia 26 ribu sekian, itu artinya sekitar 60-70 orang meninggal setiap hari akibat kecelakaan lalu lintas (Suthanaya 2016; Jusuf et al. 2017), sedangkan narkoba hanya 40-50 sehari (Leechaianan \& Longmire 2013). Hal ini berarti kecelakaan lalu lintas di Indonesia sudah harus menjadi prioritas.

Menurut Undang-undang Nomor 22 Tahun 2009 tentang Lalu Lintas dan Angkutan Jalan pasal 1 poin 24 menjelaskan definisi kecelakaan lalu lintas sebagai suatu peristiwa di jalan yang tidak diduga dan tidak disengaja melibatkan kendaraan dengan atau tanpa pengguna jalan lain yang mengakibatkan korban manusia dan/atau kerugian harta benda. Kecelakaan lalu lintas umumnya terjadi karena berbagai faktor penyebab seperti faktor manusia yang diakibatkan karena pelanggaran atau tindakan tidak hati-hati para pengguna (pengemudi dan pejalan kaki), faktor jalan, faktor lingkungan dan faktor kendaraan (Arifuddin et al. 2017; Putra 2019; Sugiyanto 2017). Salah satunya kurangnya investasi pada suatu sistem jaringan transportasi dalam kurun waktu yang cukup lama dapat mengakibatkan sistem prasarana transportasi tersebut menjadi sangat rentan terhadap kemacetan dan kecelakaan yang terjadi apabila volume arus lalu lintas meningkat lebih dari rata-rata.

Kabupaten Kediri memiliki luas wilayah sebesar 1.386,05 $\mathrm{km}^{2}$ atau 138.605 Ha yang terbagi menjadi 26 kecamatan, serta 343 desa dan 1 kelurahan. Jumlah penduduk Kabupaten Kediri berdasarkan angka sementara pada Dinas Kependudukan dan Pencatatan Sipil per 31 Desember 2015 tercatat sebesar 1.478.103 jiwa, terdiri dari laki-laki 731.222 jiwa atau 49,47\% dan perempuan 746.881 jiwa atau $50,53 \%$. Dengan semakin meningkatnya jumlah penduduk tersebut, maka meningkat juga potensi kecelakaan yang dapat terjadi (Norman \& WHO 1962; Halinen \& Jaussi 1994).

Untuk di wilayah hukum Polres Kediri terdapat 2 kawasan utama blackspot atau jalur maut terjadinya kecelakaan, antara lain: Jalur black spot Jalan Raya Tugurejo Desa Tugu Rejo Kecamatan Ngasem Kabupaten Kediri; serta jalur black spot jalan raya Dr Sudiro Husodo Desa/Kecamatan Gurah Kabupaten Kediri. Secara khusus selama kurun waktu tahun 2018, area jalur blackspot Jalan Raya Tugurejo Desa Tugu Rejo Kecamatan Ngasem Kabupaten Kediri sudah memakan korban meninggal dunia sebanyak 6 orang. Berdasarkan latar belakang di atas maka studi ini berupaya mengkaji bentuk penanggulangan terjadinya fatalitas korban kecelaakan lalu lintas di kawasan Tugurejo Ngasem Kediri, Jawa Timur.

Definisi lalu lintas dan angkutan jalan menurut pasal 1 butir 1 Undang-Undang No. 22 Tahun 2009 adalah satu kesatuan sistem yang terdiri atas lalu lintas, angkutan jalan, jaringan lalu lintas dan angkutan jalan, prasarana lalu lintas dan angkutan jalan, kendaraan, pengemudi, pengguna jalan, serta pengelolaannya.

Sedangkan pada Pasal 1 butir 2, lalu lintas didefinisikan sebagai gerak kendaraan dan orang di ruang lalu lintas jalan. Ruang lalu lintas jalan adalah prasarana yang diperuntukkan bagi gerak pindah kendaraan, orang, dan / atau barang yang berupa jalan dan fasilitas pendukung (Sasambe 2016). Pasal 1 butir 24 Undang-Undang No. 22 Tahun 2009 tentang Lalu-Lintas dan Angkutan Jalan menjelaskan bahwa yang dimaksud kecelakaan lalu lintas adalah suatu peristiwa di jalan yang tidak diduga dan tidak disengaja melibatkan kendaraan dengan atau tanpa pengguna jalan lain yang mengakibatkan korban manusia dan/atau kerugian harta benda. Menurut Djajoesman (1976) kecelakaan lalu lintas 
diartikan sebagai: Suatu kejadian yang tidak disengaja atau tidak disangka-sangka dengan akibat kematian, luka atau kerugian benda. Kecelakaan selalu mengandung unsur tidak sengaja atau yang tidak disangka sangka menimbulkan rasa heran atau tercengang kepada orang yang mengalami itu (Djaja et al. 2016).

Undang-undang Nomor 22 Tahun 2009 tentang Lalu Lintas dan Angkutan Jalan pasal 1 poin 24 menjelaskan definisi kecelakaan lalu lintas sebagai suatu peristiwa di jalan yang tidak diduga dan tidak disengaja melibatkan kendaraan dengan atau tanpa pengguna jalan lain yang mengakibatkan korban manusia dan/atau kerugian harta benda. Pasal 229 mengatur tentang penggolongan kecelakaan lalu lintas, yaitu: a) Kecelakaan Lalu Lintas ringan merupakan kecelakaan yang mengakibatkan kerusakan kendaraan dan/atau barang; b) Kecelakaan Lalu Lintas sedang merupakan kecelakaan yang mengakibatkan luka ringan dan kerusakan kendaraan dan/atau barang; c) Kecelakaan Lalu Lintas berat merupakan kecelakaan yang mengakibatkan korban meninggal dunia atau luka berat.

Secara yuridis, pengertian korban termaksud dalam Undang- Undang Nomor 13 Tahun 2006 tentang Perlindungan Saksi dan Korban, yang dinyatakan bahwa korban adalah seseorang yang mengalami penderitaan fisik, mental, dan / atau kerugian ekonomi yang diakibatkan oleh suatu tindak pidana. Melihat rumusan tersebut, yang disebut korban adalah: a) Setiap orang; b) Mengalami penderitaan fisik, mental, dan / atau; c) Kerugian waktu; d) Akibat tindak pidana.

Menurut kamus Crime Dictionary yang dikutip Waluyo (2011), victim adalah orang telah mendapatkan penderitaan fisik atau penderitaan mental, kerugian harta benda atau mengakibatkan mati atas perbuatan atau usaha pelanggaran ringan dilakukan oleh pelaku tindak pidana dan lainnya. Selaras dengan pendapat di atas adalah Gosita (1993) yang menyatakan bahwa yang dimaksud dengan korban adalah mereka yang menderita jasmaniah dan rohaniah sebagai akibat tindakan orang lain yang mencari pemenuhan diri sendiri atau orang lain yang bertentangan dengan kepentingan dan hak asasi yang menderita.

Korban juga didefinisikan oleh van Boven (2002) yang merujuk pada Deklarasi Prinsip-Prinsip Dasar Keadilan bagi Korban Kejahatan dan Penyalahgunaan Kekuasaan sebagai berikut: "Orang yang secara individual maupun kelompok telah menderita kerugian, termasuk cedera fisik maupun mental, penderitaan emosional, kerugian ekonomi atau perampasan yang nyata terhadap hak-hak dasarnya, baik karena tindakan (by act) maupun karena kelalaian (by omission)".

Secara luas pengertian korban diartikan bukan hanya sekedar korban yang menderita langsung, akan tetapi korban yang tidak langsung pun juga mengalami penderitaan yang dapat diklasifikasikan sebagai korban (Moriarty 2002; McKenzie 2006; Anjarani 2019). Yang dimaksud korban tidak langsung disini seperti isteri kehilangan suami, anak yang kehilangan bapak, orang tua yang kehilangan anaknya dan lain sebagainya.

Secara lebih spesifik menurut UU No 22 Tahun 2009 tentang Lalu Lintas Dan Angkatan Jalan menyebutkan mengenai korban kecelakaan adalah: a) Korban mati adalah korban yang dipastikan mati sebagai akibat kecelakaan lalu lintas dalam jangka waktu paling lama 30 hari setelah kecelakaan; b) Korban luka berat adalah korban yang karena luka-lukanya menderita cacat atau harus dirawat dalam jangka waktu lebih dari 30 hari sejak terjdinya kecelakaan; c) Korban luka ringan adalah korban yang tidak termasuk dalam pengertian di atas.

\section{Metode Penelitian}

Tipe penelitian ini adalah penelitian sosiologi hukum. Penelitian yang menggunakan pendekatan hukum dalam melihat fakta empiris. Dalam penelitian ini pendekatan yang digunakan adalah kualitatif dengan menggunakan metode studi kasus (case study) (Sanapiah 1990). Pendekatan masalah yang digunakan meliputi pendekatan perundang-undangan, pendekatan konsep dan studi kasus. Pendekatan perundang-undangan yaitu dengan meneliti perundang-undangan yang terkait dengan isu hukum yang diteliti yaitu tindak pidana perdagangan orang (Yin 2011). 
Sumber data atau informasi meliputi data primer dan data sekunder. Data primer adalah data yang diperoleh secara mentah kemudian di analisis lebih lanjut, berasal dari masyarakat secara langsung atau aparat penegak hukum yang berhubungan dengan penelitian ini (Soekanto \& Mamudji 1985). Sedangkan data sekunder adalah data yang diperoleh melalui studi kepustakaan dengan mempelajari literatur, tulisan ilmiah, peraturan perundang-undangan, serta dokumen yang diperoleh instansi yang terkait dengan obyek penelitian dan permasalahan yang diangkat.

Salah satu tahap yang paling penting dalam penelitian adalah menganalisis data yang telah diperoleh. Analisis data dalam penelitian ini menggunakan analisis kualitatif. Dalam penelitian kualitatif dapat dikonstruksi sebagai satu strategi penelitian yang biasanya menekankan kata-kata daripada kuantifikasi dalam pengumpulan dan analisis data, menekankan pendekatan induktif untuk hubungan antara teori dan penelitian, yang tekanannya pada penempatan penciptaan teori (generation of theory).

\section{Hasil dan Pembahasan}

Adapun langkah konkret dalam mewujudkan pembinaan fungsi satuan lalu lintas dalam rangka menciptakan keamanan, keselamatan, dan ketertiban serta kelancaran dalam berlalu lintas diwilayah hukum Polres Kediri maka dikedepankan 3 (tiga) pendekatan fungsi Kepolisian yakni pre-emtif, preventif, dan represif (Wicaksana 2018). Tujuan yang hendak dicapai tentu saja terciptanya Kamseltibcar lantas di wilayah hukum Polres Kediri dan lebih khusus sebagai upaya mengatasi permasalahan terjadinya fatalitas di Jalan Raya Tugurejo Kecamatan Ngasem Kabupaten Kediri, Jawa Timur.

\section{Pendekatan pre-emtif}

Pendekatan ini sangat penting untuk dikedepankan mengingat pencegahan secara dini melalui optimalisasi kegiatan-kegiatan bidang edukatif masih dirasa sangat perlu dan penting untuk terus dilaksanakan.

Pendekatan ini dapat dilaksanakan melalui cara-cara sebagai berikut: (1) Pendidikan masyarakat (dikmas) dalam berlalu lintas penting dilaksanakan karena dapat memberikan pencerahan kepada masyarakat sejak usia dini. Langkah konkretnya adalah sebagai berikut: a) Pelatihan Pertolongan Pertama Gawat Darurat (PPGD) kepada masyarakat yang berdomisili disekitar wilayah black spot (Parwita 2019). Isi dari materi pelatihan PPGD yang diberikan antara lain adalah penanganan korban trauma. Korban trauma adalah korban yang mengalami gangguan fisik, yaitu berupa benturan dengan benda keras. Penyebab terjadinya benturan bisa bermacam-macam, seperti jatuh, kejatuhan benda, atau kecelakaan lalu lintas. b) Melaksanakan kegiatan Police Goes to School.

Materi pembekalan kegiatan Police Goes to School antara lain adalah: (1) Sosialisasi ketertiban serta keselamatan berlalu lintas pelajar (Parwita 2019); (2) Sosialisasi tentang bahaya narkoba, miras, obatobatan terlarang dan menjaga keamanan (Wartono 2019); (3) Pembagian helm dan kaos pelopor keselamatan lalu lintas. Hasil yang ingin dicapai dalam kegiatan ini antara adalah: a) Memberikan pemahaman tentang dasar pengetahuan lalu lintas kepada pelajar; b) Mencegah laka lantas yang melibatkan pelajar; c) Menumbuhkan pengertian dan kesadaran tentang keselamatan berlalu lintas; d) Menumbuhkan pengertian dan kesadaran pemakai jalan untuk disiplin dan tertib dalam rangka keselamatan berlalu lintas; e) Membekali pengetahuan kepada para pelajar guna terwujudnya geneerasi muda pelopor keselamatan berlalu lintas; e) Terwujudnya Kamseltibcar Lantas yang kondusif di wilayah hukum Polres Kediri.

Upaya mencegah tingkat fatalitas kecelakaan lalu lintas tidak dapat dilaksanakan sendiri oleh Polisi namun dibutuhkan peranan masyarakat pula dengan cara pemberdayaan masyarakat itu sendiri (Muhammad 1998; Mahardika 2012). Pembinaan kelompok masyarakat, dalam wujud: a) Membuka komunikasi aktif dengan berbagai komunitas sosial masyarakat seperti komunitas pengendara sepeda motor (bikers), wujudnya bisa berupa pengawalan komunitas; b) Kegiatan bersama dengan kelompok penyedia jasa lalu lintas, seperti perlombaan antar tukang becak dan sopir angkot dengan melibatkan 
komunitas lainnya seperti dealer mobil/motor. Terakhir, gencarnya kampanye keselamatan berlalu lintas melalui spanduk, baliho dan media lainnya.

\section{Pendekatan preventif}

Merupakan bentuk pencegahan kecelakaan lalu lintas melalui kehadiran atau keberadaan anggota lalu lintas itu sendiri. Pendekatan ini dapat dilaksanakan melalui beberapa cara diantaranya: (1) Turjawali, pelaksanaan fungsi (pengaturan, penjagaan, pengawalan, dan patroli) dilaksanakan dengan optimalisasi peran anggota satuan lalu lintas, seperti: a) Pengaturan Harian Pagi hari, dengan menempatkan anggota gatur dititik-titik rawan kemacetan dan kecelakaan dengan konsep "Polisi Senyum"; b) Penjagaan, yakni dengan cara Penempatan anggota pada pos-pos lalu lintas yang ada dan sistem komunikasi terpadu anggota dengan menggunakan pendekatan komunikasi langsung, utamanya dalam percepatan penanganan kecelakaan lalu lintas; c) Pengawalan, dengan cara pelaksanaan pengawalan pada kegiatan-kegitan tertentu masyarakat bahkan tanpa diminta, seperti iring-iringann jenazah, ambulance dan sebagainya, pengawalan rutin pada kegiatan-kegiatan prioritas; d) Patroli yakni dengan: Patroli rutin dan terjadwal, Patroli insidentil pada titik-titik kerawanan terutama pada malam hari.

Untuk mewujudkan situasi keamanan, keselamatan, ketertiban dan kelancaran lalu lintas di Kabupaten Kediri dan tuntutan pelayanan masyarakat terhadap Polri dengan melakukan Kerjasama Lintas Sektoral Pelibatan instansi lain diluar Polri. Hal ini membuat instansi kepolisian berusaha berbenah diri dalam bidang pelayanan kepada masyarakat. Berbagai jalan di tempuh untuk meningkatkan mutu pelayanan kepada masyarakat salah satunya adalah membuat suatu program bertujuan untuk menekan fatalitas korban laka dengan melibatkan instansi terkait yang diberi nama "SI PEKA" (SIstem terpadu PEnanggulangan fatalitas korban laKA). Program ini kemudian dituangkan dalam MOU. Dengan pelaksanaan kegiatan penandatanganan MOU peresmian program SI PEKA ini diharapkan kepada instansi terkait Dinas Kesehatan Kabupaten Kediri, Dinas Pendidikan Kabupaten Kediri, Dinas Perhubungan Kabupaten Kediri, Dinas Pekerjaan Umum dan Penata Ruang Kab Kediri, Rumah Sakit Umum Daerah Kediri (RSUD), Rumah Sakit Toeloengredjo Pare, Rumah Sakit Bhayangkara Kediri, PT Perwakilan Jasaraharja (persero) Cabang Kediri, BPJS Kesehatan cabang utama Kediri dan beberapa rumah sakit dan puskesmas yang ada diwilayah hukum Kabupaten Kediri untuk ikut bertanggung jawab dalam hal penekanan fatalitas korban Laka sehingga para korban kecelakaan lalu lintas dapat segera ditangani secara cepat dan tepat dan profesional.

\section{Pendekatan represif}

Operasi rutin lalu lintas dilaksanakan utamanya guna memeriksa kelengkapan kedaraan dan kelengkapan perorangan dari para pengguna jalan raya. Pendekatan ini akan efektif dijalankan dengan melibatkan semua unsur pelaksana tugas dibidang lalu lintas. Penegakan hukum tidak harus berakhir pada tindakan tegas seperti tilang dan sebaginya namun bisa juga dikedepankan peringatan-peringatan dan himbauan sebagai penggugah kesadaran masyarakat untuk tertib berlalu lintas (Maliki 2017).

Operasi gabungan dapat dilaksanakan dengan melibatkan unsur Dinas LLAJ serta unsur militer, harapannya tidak hanya masyarakat menjadi lebih taat pada aturan jalan namun juga mencegah adanya kemungkinan anggota-anggota TNI/Polri yang melanggar aturan (Abdussalam 1997).

\section{Simpulan}

Berdasarkan analisis permasalahan dalam penelitian ini maka sebagai simpulan dijelaskan bahwa mengenai upaya Polres Kediri dalam penanggulangan fatalitas korban kecelakaan lalu lintas dilakukan dengan 3 macam pendekatan yakni pre-emtif, preventif, dan represif. Dalam pendekatan preemtif, pendidikan masyarakat sangat ditekankan disini yakni terutama mengenai pelatihan Pertolongan Pertama Gawat Darurat (PPGD) kepada masyarakat yang berdomisili disekitar wilayah Blackspot. Selain pelatihan PPGD juga dilaksanakan kegiatan Police Goes To School. Selain fokus pada pendidikan masyarakat, juga difokuskan pada pemberdayaan masyarakat dan kampanye keselamatan 
berlalu lintas melalui spanduk, baliho dan media lainnya. Pada pendekatan preventif, dilaksanakan melalui turjawali, serta melakukan kerjasama lintas sektoral dengan pelibatan instansi lain diluar Polri melalui program SI PEKA. Selanjutnya pendekatan represif yakni dilakukannya operasi rutin serta operasi gabungan demi untuk meminimalisir jumlah fatalitas korban kecelakaan lalu lintas.

\section{Daftar Pustaka}

Abdussalam R (1997) Penegakan Hukum di Lapangan oleh Polri. Jakarta : Dinas Hukum Polri.

Anjarani KE (2019) Penyelesaian kecelakaan lalu lintas pelaku anak. Jurnal Sosiologi Dialektika 14 (2):68-75.

Arifuddin A, Napirah MR \& HS NA (2017) Risk factors in road traffic accident in the city of Palu, Indonesia. Public Health of Indonesia 3 (1):23-29.

Azizirrahman M, Normelani E, \& Arisanty D (2015) Faktor penyebab terjadinya kecelakaan lalu lintas pada daerah rawan kecelakaan di Kecamatan Banjarmasin Tengah Kota Banjarmasin. Jurnal Pendidikan Geografi 2 (3):37.

Boven TV (2002) Mereka yang Menjadi Korban. Yogyakarta: Pustaka Pelajar.

Dick H (2000) Representations of development in 19th and 20th century Indonesia: A transport history perspective. Bulletin of Indonesian Economic Studies 36 (1):185-207.

Djaja S, Widyastuti R, Tobing K, Lasut D \& Irianto J (2016) Gambaran kecelakaan lalu lintas di Indonesia Tahun 2010-2014. Jurnal Ekologi Kesehatan 15 (1).

Djajoesman (1976) Polisi dan Lalu Lintas. Bandung: Bina Aksara.

Firmansyah J (2009) Kajian Geografi terhadap Kemacetan Lalu Lintas di Kota Surakarta Tahun 2008. Skripsi: Universitas Muhammadiyah Surakarta.

Gosita A (1993) Masalah Korban Kejahatan. Jakarta: CV Akademika Pressindo.

Gunoto P, Irsyam M \& Wijaya TK (2016) Pengembangan sistem traffic lights berdasarkan kepadatan kendaraan menggunakan PLC. Jurnal Dimensi 4 (3).

Halinen MO \& Jaussi A (1994) Fatal road accidents caused by sudden death of the driver in Finland and Vaud, Switzerland. European Heart Journal 15 (7):888-894.

Hidayati A \& Hendrati LY (2016) Analisis risiko kecelakaan lalu lintas berdasar pengetahuan, penggunaan jalur, dan kecepatan berkendara. Jurnal Berkala Epidemiologi 4 (2).

Jusuf A, Nurprasetio IP \& Prihutama A (2017) Macro data analysis of traffic accidents in Indonesia. Journal of Engineering and Technological Sciences 49 (1):132-143.

Mahardika KA (2012) Penegakan Hukum Lalu Lintas guna Mewujudkan Efek Bagi Pelanggar di Wilayah Polres Buleleng. Jakarta: STIK-PTIK.

Maliki A (2017) Efektivitas penegakan hukum dengan tilang untuk mengurangi pelanggar lalu lintas di Polres Kudus. Indonesian Journal of Police Studies 1 (1):295-352.

McGee T (1994) The future of urbanisation in developing countries. The case of Indonesia. Third World Planning Review 16 (1).

McKenzie IK (2006) Forcing the police to open fire: A cross-cultural/international examination of police-involved, victim-provoked shootings. Journal of Police Crisis Negotiations 6 (1):5-25.

Moriarty LJ (2002) Policing and Victims (Vol. 20). Upper Saddle River, NJ: Prentice Hall.

Muhammad F (1998) Praktik Penegakan Hukum. Jakarta: Balai Pustaka.

Norman LG \& World Health Organization (1962) Road Traffic Accidents: Epidemiology, Control, and Prevention.

Leechaianan Y \& Longmire DR (2013) The use of the death penalty for drug trafficking in the United States, Singapore, Malaysia, Indonesia and Thailand: A comparative legal analysis. Laws 2 (2):115-149.

Parwita IM (2019) Optimalisasi satuan lalu lintas Polres Gresik dalam menanggulangi kecelakaan lalu lintas akibat pelanggaran muatan. Jurnal Sosiologi Dialektika 14 (1):44-51.

Prayitno B (2007) Analisa pengaruh faktor pendapatan perkapita harga kendaraan bermotor dan jumlah penduduk mempengaruhi permintaan kendaraan bermotor Kota Surabaya. Equilibrium: Jurnal Ekonomi-Manajemen-Akuntansi 5 (3):197-216.

Putra KAY (2019) Penanganan terhadap kecelakaan lalu lintas di Kota Probolinggo. Jurnal Sosiologi Dialektika 14 (1):59-67. 
Ridho II \& Raharjo MR (2018) Aplikasi prediksi penjualan kendaraan bermotor. Technologia: Jurnal Ilmiah 9 (2):89-94.

Santosa SP, Mahyuddin AI \& Sunoto FG (2017) Anatomy of injury severity and fatality in Indonesian traffic accidents. Journal of Engineering and Technological Sciences 49 (3):412-422.

Sanapiah F (1990) Penelitian Kualitatif (Dasar-Dasar dan Aplikasi). Malang: YA3 Malang.

Sasambe RO (2016) Kajian terhadap penyelesaian pelanggaran peraturan lalu lintas oleh kepolisian. Lex Crimen 5 (1).

Soehodho S (2017) Public transportation development and traffic accident prevention in Indonesia. IATSS Research 40 (2):76-80.

Soekanto S \& Mamudji S (1985) Penelitian Hukum Normatif. Jakarta: Rajawali Pers.

Sugiyanto G (2017) The cost of traffic accident and equivalent accident number in developing countries (case study in Indonesia). ARPN Journal of Engineering and Applied Sciences 12 (2):389-397.

Suthanaya PA (2016) Analysis of fatal accidents involving motorcycles in low income region (case study of Karangasem Region, Bali-Indonesia). In International Journal of Engineering Research in Africa 19:112-122. Trans Tech Publications Ltd.

Waluyo B (2011) Viktimologi Perlindungan Hukum Terhadap Korban Kejahatan. Jakarta: Sinar Grafika.

Wartono NE (2019) Pengawasan penggunaan senjata api legal di wilayah hukum Kepolisian Daerah Metro Jaya. Jurnal Sosiologi Dialektika 14 (1):1-8.

Wicaksana AR (2018) Kewenangan tembak di tempat oleh aparat terhadap pelaku kejahatan. Jurnal Sosiologi Dialektika 13 (2):114-121.

Wicaksono D, Fathurochman RA, Riyanto B \& Wicaksono YI (2014) Analisis kecelakaan lalu lintas (Studi kasus-Jalan Raya Ungaran-Bawen). Jurnal Karya Teknik Sipil 3 (2):345-355.

World Health Organization (2015) Global Status Report on Road Safety 2015.

Yin RK (2011) Studi Kasus: Desain dan Metode. Jakarta: Rajagrafindo Persada. 